Pregledni članak UDK 165.62(045)Schmitz, H.

doi: $\underline{10.21464 / f i 37304}$

Primljeno 29. 8. 2017.

\title{
Biljana Radovanović
}

Univerzitet u Nišu, Filozofski fakultet, Ćirila i Metodija 2, RS-18000 Niš

biljana.radovanovic9@gmail.com

\section{Koncept tjelesne komunikacije kod Hermanna Schmitza}

\begin{abstract}
Sažetak
Autoričina je namjera prikazati pojam tjelesne komunikacije kod Hermanna Schmitza. Prvo će biti skiciran kontekst u kojemu se uvodi taj pojam: Schmitzova filozofija tjelesnosti pomoću koje osnivač nove fenomenologije pokušava ukazati na doživljajnu dimenziju tjelesnosti. Analizirat će se i primjerima ilustrirati forme tjelesne komunikacije (utjelovljenje i istjelovljenje). Posebna pažnja bit će posvećena fenomenu pogleda. Koncept tjelesne komunikacije u zasebnom će odjeljku biti primijenjen na problem razumijevanja izraza. Razmatrajući ovu tematiku, osvrnut ćemo se i na moderne tendencije informatizacije tjelesnosti.
\end{abstract}

\section{Ključne riječi}

Hermann Schmitz, nova fenomenologija, tjelesna komunikacija, utjelovljenje, pogled, istjelovljenje, razumijevanje izraza

\section{Uvod}

U filozofskoj tradiciji, tijelo se najčešće sagledavalo i objašnjavalo kroz uspoređenje s dušom. ${ }^{1}$ Međutim, u suvremenoj filozofiji pojam tjelesnosti razmatra se kao zaseban filozofski problem. Sve više raste interes za proučavanjem tijela i tjelesnih fenomena. Višestruki su razlozi pojave i jačanja ovog interesa: kritika idealističkog i racionalističkog ignoriranja uloge tijela u formiranju svijesti o svijetu, kao i samosvijesti, razvoj filozofije života i filozofske antropologije, povezivanje s biologijom, fiziologijom i znanošću o kretanju, prepoznavanje religioznih motiva marginalizacije tijela kao istinskog filozofskog predmeta i otkrivanje društvene dimenzije tjelesnosti (posebno u sociologiji i kulturološkim znanostima).

Tematiziranje problema tjelesnosti kreće se od rasprava o razlozima zanemarivanja ove teme do pitanja zloupotrebe tijela u medijske i komercijalne svrhe. Međutim, rastući interes za proučavanje tijela nije vezan samo za filozofiju. U velikoj su se mjeri znanosti posvetile istraživanju funkcioniranja i građe svih segmenata ljudskog tijela, posebno one medicinske, u cilju liječenja, korekcije ili preventivnog sprečavanja razvoja bolesti. Ruski filozof Mihail Ėpšteîn ističe da se na granici dvadesetog i dvadeset i prvog stoljeća drastično mijenja odnos prema tijelu s obzirom na to da raste značaj medicinsko-sportske kom-

1

Odnos tijela i duše, često svođen na relaciju materija-duh, tematizira se u filozofiji još od vremena Platona i Aristotela. Dok ono duševno može podrazumijevati uključenost i odnos prema tijelu, duh i tijelo se, kao kod Descartesa, koji ističe razliku između protežne stvari (res extensa) i misleće stvari (res cogitans), promatraju u svojoj odvojenosti. 
ponente naše civilizacije. Jedna od vodećih tema u svim vrstama medija je jačanje, njega i izlječenje tijela. Èpšteîn ističe da

»Nikada ranije znanost nije prodirala tako duboko u tajne građe tijela, u ćelijsko-molekularne mehanizme starenja i nasljednosti, u biokemiju mozga itd. Istovremeno (...) kao da se ono [tijelo] približava nekoj granici svoje biološke evolucije, čijim će prelaskom izgubiti niz svojih odredbenih svojstava: cjelovitost i jediničnost, individualnu neobnovljivost, prostorno-vremensku ograničenost. $\ll^{2}$

Poseban značaj tijelu pridaje fenomenološka filozofija. Mada kod Husserla, osnivača te vrste filozofije, tematika tjelesnosti još ne igra tako značajnu ulogu (izuzeci su tematiziranje diferencije između živog (pravog) i neživog tijela u slučaju optičkih varaka ili proučavanje pokreta i položaja (kinestezija), kasnije su fenomenolozi otkrili tijelo kao legitimni predmet svojih razmatranja. ${ }^{3}$ Prije svega, tu treba navesti francuske fenomenologe Mauricea Merleau-Pontyja $^{4}$ i Jean-Paula Sartrea. ${ }^{5}$

\section{Schmitzov koncept tjelesne komunikacije}

\subsection{Pojam tjelesnosti u novoj fenomenologiji Hermanna Schmitza}

Najrazrađeniju koncepciju tjelesnosti u fenomenologiji nalazimo u mnogobrojnim spisima Hermanna Schmitza, osnivača »nove fenomenologije«. Schmitz tijelo shvaća ne samo kao medij kontakta s okolnim svijetom nego i kao važan izvor samospoznaje. Posebno se opire zaboravljanju tjelesnog iskustva u klasičnoj filozofskoj tradiciji, kao i pokušajima puke funkcionalizacije tijela u suvremenim filozofskim tendencijama, poput naturalizma. Moglo bi se reći da je najviše pažnje u svom obimnom dijelu posvetio subjektivnoj strani tjelesnog iskustva. Njegova filozofija tijela je, u stvari, detaljno razrađena fenomenologija tjelesnog osjećanja. Schmitza, prije svega, zanima sljedeće pitanje: kako doživljavam vlastito tijelo? Za razliku od nekih drugih značajnih teoretičara u dvadesetom stoljeću, koji su se tjelesnošću bavili na apstraktan način, Schmitz nastoji filozofirati tijelom. U izvjesnom smislu, on nastavlja tradiciju razgraničenja fizičkog i živog tijela, ${ }^{6}$ posebno onu koja je vezana za ime filozofskog antropologa Helmutha Plessnera, ${ }^{7}$ ali je ujedno i nadograđuje i još više specificira. Za Schmitza, Leib je tijelo koje osjeća, odnosno pomoću kojega mi osjećamo, dok je Körper tijelo koje može služiti kao sredstvo i instrument za ispunjenje naših namjera i svrha.

Kada Schmitz govori o tijelu, onda on ne misli na ovo vidljivo i dodirljivo tijelo, nego ima na umu osjetljivo tijelo, odnosno tijelo koje osjeća. Tako poimano tijelo sažima sve one tjelesne reakcije koje se spontano javljaju kao odgovor na određenu situaciju ili izvanjske uvjete kojima je ono izloženo. Dakle, Schmitz tjelesnost vidi u uskoj vezi s osjećajnošću. ${ }^{8}$ Do koje mjere on tu povezanost smatra značajnom vidi se i prema tomu što, prema njegovom mišljenju, imati tijelo (Leib) znači moći biti prestrašen. Kada se naglo uplašimo, osjećamo kako nam se tijelo steže i grči, naprosto vlastitim tijelom osjećamo uskoću - kao da nas je neko sabio u ugao. U takvim situacijama odjednom doživljavamo pet dimenzija koje čine izvorno iskustvo naše egzistencije: ovdje, sada, ovo (ne bilo što), bivstvo (stvarnost) i vlastitost. Taj petostruki doživljaj Schmitz naziva primitivna sadašnjost (primitive Gegenwart). ${ }^{9}$ Zbiva se u egzistencijalno napetim situacijama, npr. kada smo preplašeni, kada nas presječe oštra bol, kada doslovno izgubimo tlo pod nogama i sl. U tom trenutku imamo određenu svijest o sebi, odnosno osjećamo sebe u prvoj temeljnoj reakciji integriranja, sažimanja i porasta svih snaga u nama. To sebeosjećanje (Sichspüren) prethodi svakom obliku identifikacije putem kognitivnih radnji 
kao što je npr. pripisivanje određenih stanja svijesti samomu sebi. U momentima kada je čovjek doveden u neku opasnost, on sebe osjeća i doživljava kroz osobne tjelesne reakcije i radnje. Da bi objasnio automatske, elementarne pokrete koje u takvim situacijama pravi tijelo, Schmitz koristi izraz micanje (Regung) koje je uvijek u uskoj vezi sa stanjima straha, boli, umora, gladi,

Mihail Epštejn [Mihail Epstein], Filozofija tela, prevela Radmila Mečanin, Geopoetika, Beograd 2009., str. 15

3

Držeći se po strani od aktualnih tokova fenomenološkog tematiziranja pojma tijela Henri Bergson u spisu Duša i tijelo i dalje tijelo sagledava kroz odnos prema duši. Smatra da je tijelo zatočeno u sadašnjosti, ograničeno na prostor koji trenutno zauzima i da na vanjske poticaje reagira mehanički. Međutim, budući da mi poimamo mnogo dalje i više, nego što su trenutne vremensko-prostorne granice, ono što nadilazi tijelo $i$ što ga pokreće naša je duša. Usp. Anri Bergson [Henri Bergson], Duša telo, u: O smehu, preveo Srećko Džamonja, Vega media, Novi Sad 2004., str. 163-199.

Razmatrajući percepciju, odnosno naše iskustvo, Merleau-Ponty pokazuje da se čovjekovo tijelo ne bi trebalo promatrati samo kao objekt kojim se bave određene znanosti. Čovjek je kroz tijelo, kao trajno stanje iskustva, u svojoj percepciji otvoren prema svijetu. On smatra da je percepcija konstitutivna dimenzija kroz koju se sagledava korporealnost svijesti kao intencionalnost tijela. Usp. Maurice MerleauPonty, Fenomenologija percepcije, preveo Anđelo Habazin, Veselin Masleša, Sarajevo 1990., str. 93-210.

5

Jean-Paul Sartre pravi razliku između načina na koji drugi mogu vidjeti naše tijelo kao objekt u svijetu i pristupa kojim ga mi sagledavamo i doživljavamo iznutra, na subjektivan način. »Biće-za-sebe mora biti potpuno tijelo i potpuno svijest: ono ne može biti potpuno izjednačeno s tijelom. Isto tako biće-za-drugog je potpuno tijelo; tu ne postoji 'psihički fenomen' koji bi se izjednačio s tijelom, iza tijela ne postoji ništa, ali je tijelo potpuno 'psihičko'.« Vidi: Žan-Pol Sartr [Jean-Paul Sartre], Biće i ništavilo II, preveo Mirko Zurovac, Nolit, Beograd 1984., str. 313.

6

U njemačkom jeziku i u njemačkoj filozofskoj tradiciji pravi se razlika između fizičkog tijela (Körper) i živog (osjetljivog) tijela (Leib).

Plessnerova teorija ekscentrične pozicionalnosti temelji se na razlikovanju dva aspekta ljudske tjelesne egzistencije, na fizičkom tijelu (Körper) i živom tijelu (Leib). »Živo tijelo i fizičko tijelo se ne poklapaju, iako ne čine materijalno međusobno razdvojive sustave, nego jedan te isti. Taj dvostruki aspekt je radikalan. (...) Oba aspekta postoje jedan pokraj drugoga, posredovani samo $u$ točki ekscentričnosti, u Ja koje se ne može objektivirati. (...) Tako okolnom svijetu, u protusmislenoj usklađenosti, odgovara unutarnji svijet, svijet »u« živom tijelu, ono što je živo biće samo. No ni ovaj svijet nije jednoznačno određen jednim aspektom. Zakon ekscentričnosti određuje dvostruki aspekt njegove egzistencije kao duše i doživljaja.« Vidi: Helmuth Plessner, Stupnjevi organskoga i čovjek. Uvod u filozofsku antropologiju, preveo Božo Dujmović, Naklada Breza, Zagreb 2004., str. 268-269. Iako Plessner ističe i upotrebljava razliku između fizičkog i živog tijela, on koristi poseban izraz Körperleib kojim želi naglasiti i njihovu jedinstvenost.

8

Nasuprot Schmitzu, Hans H. Grelland naglašava dvostrukost doživljaja tijela. S jedne strane, identificiramo se s tijelom preko kojega osjećamo i sebe doživljavamo kao slobodno i svjesno biće. S druge strane, »... moderna biologija daje bogat uvid u tijelo kao fizičko-kemijski sistem, kao i sve detaljniju identifikaciju načina na koji mjerljivi fizički procesi u mozgu i u drugim dijelovima tijela, koji se mogu lokalizirati, prate misli i osjećanja«. Vidi: Hans Herlof Grelan [Hans Herlof Grelland], Filozofija osećanja, prevela Ratka Krsmanović, Geopoetika, Beograd 2007., str. 51-52. Ovo su dva potpuno drugačija iskustva tijela koja je nemoguće ujediniti u jednu teoriju.

9

Schmitz primitivnu sadašnjost opisuje na sljedeći način: »Radi se o prijemčivosti za usud bivanja iščupanima iz nerazdjeljenog kontinuuma koji je, ujedno, klizeće trajanje i širina, i da se naprosto nađemo izopćeni na jednom vrhu koji je u potpunoj, ali neodređenoj jednoznačnosti: ovdje, sada, ovo (ne bilo što), bivstvo (stvarnost) i naša vlastitost, ali ne različito $u$ pet vidova, nego to petostruko u jednoj vrsti stapanja koje se tek prilikom razvijanja, kada se određenost javlja kao takva, razilazi u pet pravaca.« Vidi: Hermann Schmitz, Was ist Neue Phänomenologie?, Ingo Koch Verlag, Rostock 2003., str. 24. Usp. Hermann Schmitz, Der Leib, Walter de Gruyter, Berlin, Boston 2011., str. 74-78. 
žeđi i sl. Iz ovih teza jasno je u kojemu smislu Schmitz daje prednost tijelu u odnosu na kognitivnu samorefleksiju.

Tijelo koje sebe osjeća ima vlastitu dinamiku čiji je stožer vitalni poticaj (der vitale Antrieb) sastavljen iz tendencija sužavanja (Engung) i širenja (Weitung). Te tendencije ukrštaju se, ali se isto tako mogu i razilaziti. Kada su ukrštene, Schmitz sužavanje naziva napetošću (Spannung), a širenje nabreknućem (Schwellung). Kada se razdvoje, on sužavanje naziva privativnim sužavanjem, a širenje koje se odvaja privativnim širenjem. Privativno sužavanje možemo predočiti na primjeru prepada koji nas uzdrma, ali koji nas ne muči poput bola koji se stvara u antagonizmu sužavanja i širenja. U pojedinim micanjima dominira jedna od tendencija, dok je druga slabije izražena; tako npr. u strahu i boli prevladava sužavajuća napetost dok, na primjer, u micanju naslade i obuzetosti gnjevom dominira nabreknuće u odnosu na suprotstavljenu napetost. Iz sjedinjenosti i združenosti spomenuti momenti mogu se izdvojiti. Privativno širenje možemo predočiti na primjeru olakšanja koje poput blagotvornog umora opušta naše tijelo. Pored sužavanja i širenja postoji pravac (Richtung) kao komponenta tjelesne dinamike uskoće i širine. On posreduje između sužavanja i širenja tako što ireverzibilno vodi iz uskoće u širinu, a može se opisati i kao širenje koje na neki način preuzima uskoću. Primjeri za takvo posredovanje između sužavanja i širenja u vidu tjelesnog pravca koncentriran su pogled ili isprekidan udisaj. Širenju, sužavanju i pravcu, u sklopu tjelesne dinamike, Schmitz dodaje dvije zasebne tendencije: protopatičku ${ }^{10} \mathrm{i}$ epikritičku $u^{11}$ tendenciju. Prva, protopatička, bliža je širenju, a druga, epikritička, bliža je sužavanju. Međutim, postoje i slučajevi protopatičkog sužavanja (npr. mamurluk poslije pretjeranog konzumiranja alkohola) i epikritičkog širenja (npr. poskakujući razdragan hod).

\subsection{Pojam i vrste tjelesne komunikacije}

Jedna od glavnih tema starije fenomenologije odnos je prema Drugom - intersubjektivnost. I u Schmitzovoj novoj fenomenologiji ${ }^{12}$ razmatra se ova relacija, ali se prvenstveno promatra i analizira odnos tijela jednog aktera prema tijelu nekog drugog. Stoga bismo mogli govoriti o svojevrsnoj interkorporealnosti. Da bi označio taj, ne baš često tematiziran, odnos, Schmitz se služi izrazom tjelesna komunikacija.

»Tjelesna komunikacija zbiva se onda kada tijelo (Leib), koje se održava kroz napetost i cjelovita micanja, biva uključeno u tjelesnu dinamiku koja ga razdvaja ili nadmašuje tako što ga spaja s nečime. $\ll^{13}$

Schmitz razlikuje dvije vrste tjelesne komunikacije: tzv. utjelovljenje (Einleibung) kao vitalni poticaj (der vitale Antrieb) i tzv. istjelovljenje (Ausleibung) kao privativno širenje (die privative Weitung).

Da bi se razvila tjelesna komunikacija, potreban je izgrađen odnos prema predmetu. Schmitz kritizira stariju fenomenologiju Husserla i Schelera, čije se predstave o predmetima fokusiraju na pojedinačne stvari na koje se usmjeravaju intencionalni činovi svijesti. Također, prebacuje im to što se naknadno na pojedinačne stvari vežu dalja značenja (stanja stvari, programi, proble$m i)$. Prema Schmitzovom mišljenju, predmet ne mora biti izvana »prinesen« vlastitom tijelu, nego se može nalaziti u njemu. Primjer koji dobro ilustrira ovu tezu može se uočiti u situaciji u kojoj osjećamo bol. Doduše, bol je lično psihofizičko stanje, ali je isto tako neka vrsta »natjecatelja« s kojim se čovjek, koji ga osjeća, mora konfrontirati. 
Schmitz imenuje zasebnu ontološku kategoriju da bi označio jedan tip predmeta koji je bitan za antagonističko utjelovljenje - to su tzv. polustvari (Halbdinge). Polustvari su, primjerice, glas (čovjeka ili životinje), vjetar, električni udar, osjećaj gubitka ravnoteže, poluzvukovi poput piska, kapanje u pravilnim ritmičkim razmacima, melodije, problemi koji okupiraju čovjeka, bol koji se konstantno javlja, nepodnošljiva jara, oštra zima, osjećaj beskrajnog trajanja vremena u kojem se ništa ne događa (osjećaj da je vrijeme stalo) i sl. Polustvari se odlikuju trajanjem koje se može iznenada prekinuti i neposrednom uzročnošću:

»Polustvari su tu, nestaju i ponovo se javljaju, a da nema smisla pitati gdje su bile u međuvremenu. $\ll^{14}$

Schmitz kaže da to pitanje - gdje su polustvari bile u međuvremenu - znači sljedeće:

»Dok u slučaju stvari, između njih kao uzroka i posljedice, stoji utjecanje (npr. između kamena i udaranja ili pomicanja čaše je udar, između sredstava za spavanje i spavanja je uzimanje), kod polustvari koincidiraju uzrok i utjecaj. $\ll^{15}$

Polustvari se mijenjaju, s vremena na vreme javljaju se i iščezavaju, $s$ tim da mi njihovo nestajanje ne doživljavamo kao gubitak, niti smo iznenađeni kada one minu ili se ponovo pojave. Čovjek koji je pogođen polustvarima ne osjeća ih kao dio sebe (ili bar ne u potpunosti kao npr. kod bola), nego ih doživljava kao vanjske sile i moći koje zahvaćaju i obuzimaju njegovo tijelo. Da bi se nešto, što Schmitz imenuje kao polustvar, moglo identificirati kao takvo, naše tijelo mora ga doživjeti i prepoznati kao određenu cjelinu koja u specifičnom smislu djeluje na nas. Može se reći da mi polustvari osjećamo tek kroz njihov utjecaj na naše tijelo. Prema polustvarima tijelo formira odnos konfrontacije i otpora i u izvjesnom se smislu kroz svoje reakcije nastoji suprotstaviti pritiscima koji se nad njim provode.

\subsubsection{Utjelovljenje}

Schmitz razlikuje optičko utjelovljenje i taktilno utjelovljenje. Tipičan primjer optičkog utjelovljenja predstavlja pogled. Pogled je viđenje stvari, bića i odnosa. On uvijek podrazumijeva shvaćanje i sagledavanje sućine stvari. Karakterističan primjer optičkog utjelovljenja, koji daje Schmitz, međusobno je odmjeravanje partnera.

»Razmjena pogleda u prenesenom je smislu jedna vrsta borbe u ringu zbog strukture vitalnog poticaja kakva se u utjelovljenju proteže na partnera, u [pravoj] borbi u ringu ona se s egzemplarnom jasnoćom prikazuje kao fluktuirajuća razmjena prevage napetosti i nabreknuća, raspodijeljene na oba partnera. $«^{16}$

10

Protopatička tendencija je neodređeno rasprostiranje bez konkretnog pravca i oštrine.

11

Epikritička tendencija je artikulirano, određeno, usmjereno i koncentrirano širenje.

12

Schmitz upotrebljava izraz nova fenomenologija da bi njime imenovao svoje specifično filozofsko stanovište koje se značajno razlikuje od ranijih fenomenoloških učenja.
13

H. Schmitz, Der Leib, str. 29

14

H. Schmitz, Ausgrabungen zum wirklichen Leben. Eine Bilanz, Karl Alber Verlag, Freiburg, München 2016., str. 185.

15

Ibid., str. 186.

16

H. Schmitz, Der Leib, str. 32. 
$\mathrm{Na}$ strani promatrača, pogled je jedan tjelesni pravac, a na strani onog koji je pogođen pogledom, pogled je polustvar diskontinuiranog trajanja i neposrednog uzročnog djelovanja. Pogled drugog pogađa me sužavajući me, a ja pak svojim pogledom, šireći ga, pogađam onog drugog koji pak njega sužava, tako da bismo mogli reći da se prilikom naizmjenične razmjene pogleda sužavanje i širenje užljebljuju i čine jedan sklop. Svaka razmjena pogleda proizvodi vitalni poticaj u kojemu se sužavanje i širenje bore za prevlast, tako da je svaki pogled nastojanje da se nametne nadmoć nad drugim. Susret dvaju pogleda ujedno je i borba oko dominacije. ${ }^{17}$ Iz našeg iskustva znamo da nije jednostavno ni lako istrpiti nečiji pogled, naročito ako osoba, gledajući nas drsko i prodorno, želi proniknuti u naše misli ili nam nametnuti osjećaj razotkrivenosti ili pročitanosti u svojim namjerama.

»Pogledi su poput koplja, koje doduše ne prodire u vidljivo i dodirljivo fizičko tijelo, ali zato prodire neizmjerno duboko u osjetljivo živo tijelo. ${ }^{18}$

Onaj tko nije u stanju izdržati da ga drugi promatra, spušta svoj pogled ili ga skreće u drugom pravcu. ${ }^{19}$ Iako, u prvi mah ne čini se da su tako najdominantniji pogledi oni u kojima se izražava pokornost, kao i oni koji su puni ljubavi jer u sebi nose veliku dozu sugestivnosti i sadrže kompleksan sklop informacija i poruka. Putem pogleda, kojim se nastoji izraziti naredba ili sugestija, utječe se i na životinje, bilo da ih nastojimo pripitomiti, dresirati ili želimo na neki način komunicirati s njima. Posebno omiljen primjer kod Schmitza onaj je o pogledu koji nekome pomaže snaći se u gradskoj gužvi kada se probija kroz gomilu ljudi s kojima nastoji ne sudariti se. Pješaci koji se u vrevi kreću, hodaju i koordiniraju svoje pokrete u modusu antagonističkog utjelovljenja putem usputnih pogleda. Bez nekog posebnog proračunavanja, ljudi se pogledom orijentiraju i na taj način koordiniraju i usmjeravaju svoje kretanje. Stoga, pogled djeluje ne samo kao polustvar nego i kao tjelesni pravac, tj. ono što tijelo usmjerava i vodi.

Posebnu pažnju Schmitz pridaje taktilnom utjelovljenju. U situaciji taktilnog utjelovljenja odvija se proces međusobnog usklađivanja i koordiniranja pokreta dvaju tijela koja sudjeluju u zajedničkoj radnji ili kretanju. Stisak ruke, odnosno rukovanje, očigledan je primjer taktilnog utjelovljenja dvije osobe koje se u kontaktu međusobno usklađuju, čime konstituiraju svoju tjelesnost. U tomu smislu, dodir je čulo koje je tjelesnije od ostalih čula. Taktilno utjelovljenje ne mora podrazumijevati usklađivanje samo dvaju tijela, nego u proces zajedničkog djelovanja može biti uključen veći broj osoba. Za primjer takvog vida suptilnog i preciznog usklađivanja Schmitz navodi situaciju zajedničkog muziciranja članova orkestra. ${ }^{20}$ Postupci međusobnog usklađivanja zahtijevaju naizmjenično podešavanje i neprekidno reagiranje na poteze drugog, što potpuno i u cjelini involvira sudionike i angažira njihovu cjelovitu pažnju pri zajedničkom radu. Utjelovljenje se može intenzivirati tamo gdje je vitalni poticaj izrazito visok i jak. U takvim slučajevima onaj tko je uključen u razmjenu može naći zadovoljstvo ili čak ushićenje u međusobnom predâvanju, što se i dešava npr. u erotskom odnosu. ${ }^{21}$ Da bi bilo koje zajedničko djelovanje moglo otpočeti, neophodno je međusobno usklađivanje. Pojedine radnje aktera u odnosu ne mogu se ni obaviti ako kretnje ljudi nisu sinkronizirane i dozirane u intenzitetu, npr. da bi dvije osobe pilile drvo ili vozile kajak potrebno je da im kretnje budu dovedene u sklad s obzirom na pravac i jačinu izvedenih pokreta.

Schmitz smatra da se utjelovljenje ne događa samo s drugim tijelima nego i s prirodom i prirodnim silama kojima se čovjek odupire ili koje nastoji savlada- 
ti. Uvjet preživljavanja u ekstremnim klimatskim neprilikama ili u situacijama neposrednih elementarnih nepogoda taj je da čovjek odgovori na izazove koji su pred njim i sačuva svoje tijelo od predâvanja onome što ga može u potpunosti nadvladati i ugroziti. Balansiranje i otpor nadirućoj snazi prirode mobilizira snage tijela da bi se čovjek očuvao i izborio u ovom odnosu. Ponekad ljudi, baveći se ekstremnim sportovima ili učestvujući u istraživačkim ekspedicijama, sami sebi postavljaju zadatak odnosno izazov utjelovljenja s divljom i nepristupačnom prirodom, što od njih zahtijeva nadljudske napore, brze reakcije i maksimalnu izdržljivost i snalaženje, npr. kada planinar pokušava savlada ekstremnu visinu ili strmu padinu, ili kad plivač nadvladava jake valove i sl. Model taktilne tjelesne komunikacije Schmitz pokušava predočiti i na primjerima utjelovljenja čovjeka i životinje, uzimajući kao paradigmatičan slučaj usklađivanje pokreta jahača i konja pri jahanju. Budući da se radi o dovođenju u sklad dvije različite vrste živih bića između kojih je komunikacija problem, utjelovljenju prethodi nastojanje da se životinja privoli na to da u odnosu dođe do međusobnog usklađivanja.

Nekada se može desiti da samo jedna strana ima vitalni poticaj, odnosno da neko u odnosu može imati mehanički, a onaj drugi vitalni poticaj. Ovakav vid utjelovljenja može se detektirati na primjeru bilo kojeg odnosa čovjeka i mašine, npr. vozača i automobila, motocikliste i motora itd. Da bi se što lakše i uspješnije ostvario kontakt živog tijela s neživim, potrebne su tjelesno bliske kvalitete vezivanja (Brückenqualitäten) koje se mogu osjetiti na tijelu,

17

Jean-Paul Sartre ističe da razumijevanje drugog zavisi od mogućnosti da budem-viđenod-njega. Izvoran odnos mene i drugog svakodnevan je odnos u kojemu stječem iskustvo bivanja gledanim od drugoga u svakomu trenutku. Pogled drugog je, kao nužan uvjet moje objektivnosti, destrukcija svake objektivnosti za mene. Žan-Pol Sartr [Jean-Paul Sartre], Biće i ništavilo I, preveo Mirko Zurovac, Nolit, Beograd 1984., str. 264-309.

18

H. Schmitz, Der Leib, str. 33.

19

Ponekad, osoba koja ispitivački gleda namjerno izbjegava »primiti« uzvratni pogled onog tko je promatran, a koji se kroz svoj odgovor želi suprotstaviti. Izbjegavajući primiti povratnu reakciju, odbija se mogućnost da se u razmjeni pogleda promjene pozicije u već uspostavljenoj neravnoteži odnosa, kao i da se prihvati utjecaj od osobe koja se tretira samo kao promatrani objekt. Èpšteîn naglašava da ponekad nije lako povući granicu između npr. toplog i hladnog pogleda jer čulo vida, usprkos svojoj sposobnosti izvanjštenja, zbog svoje udaljenosti od objekta nije u stanju nanijeti neposrednu bol te se ove krajnosti teže razlučuju nego u slučaju npr. čula dodira. Usp. M. Epštejn [M. Epstein], Filozofija tela, str. 45.

20

Uspješnost neke radnje zavisi od mogućnosti da se akcije osoba, koje su uključene u zajedničko djelovanje, brzo i efikasno podese i usklade. Dobar primjer za to je koordiniranje kretanja igrača u bilo kojemu timskom sportu. Učinak koji postiže ekipa zavisi od toga u kojoj je mjeri na djelu timski rad, dobro sporazumijevanje članova tima i koordiniranje djelovanja u zajedničkim akcijama. U pojedinim sportovima, poput npr. sinkroniziranog plivanja, upravo se vrednuje i ocjenjuje ljepota i preciznost međusobne usklađenosti. Ukoliko stvar postavimo šire, utoliko napori čitavog društva, a ne samo pojedine grupe ili kolektiva, kada teže opipljivom učinku, moraju biti stavljeni u službu zajedničkog i konstruktivnog pravca. Uspješnost svake akcije koja ima širi društveni značaj zavisi od udruženog i usuglašenog djelovanja svih njenih članova. 21

Èpšteîn ističe da je osobnost erotike fokusiranost na tuđu želju, a da je seksualnost usmjerenost na nečije tijelo. U erotskom zanosu čovjek ne želi vladati tuđim tijelom, nego tuđom željom. Erotska žudnja htijenje je da nas predmet žudnje želi. Usp. M. Epštejn [M. Epstein], Filozofija tela, str. 97-102. Mutatis mutandis, primjenjujući razliku između erotike i seksualnosti na Schmitzovu terminologiju, optičko utjelovljenje u tomu smislu odgovaralo bi erotskom zanosu, a taktilno utjelovljenje odgovaralo bi seksualnosti. 
ali isto tako mogu biti opažene na oblicima koji se kreću. Tako i predmet koji posjeduje te kvalitete, a nema vlastiti vitalni poticaj, može biti partner u zajedničkom vitalnom poticaju utjelovljenja. Schmitz razlikuje dvije vrste takvih kvaliteta: sugestije kretanja (Bewegungssuggestionen) ${ }^{22}$ i sinestetski karakteri (synästhetische Charaktere). ${ }^{23}$

Neko kretanje dobiva određene kvalitete putem sugestija, pa tako npr. hod može djelovati kao lagan, poletan, trom, nespretan, nezgrapan, energičan, žustar i sl. Čak i najsitniji pokreti tijela obiluju tom vrstom sugestija, npr. kada se oči neznatno otvore, putem varijacije njihovih pokretnih sugestija, pogled se može protumačiti kao gesta molbe, zavođenja, predavanja, ironije i sl. Schmitz navodi primjer koliko može biti nepristojno kada se prstom pokaže na ljude u blizini jer ta kretnja, iako je neznatna, sugestivno obilježava nešto izvan sebe i u negativnom kontekstu ga izdvaja. Ovakav pokret sebe transcendira, ukazujući na nešto drugo što se označava, naglašava i razotkriva. Pokazivanje prstom na drugog djeluje poput noža koji se zariva u onog na koga se pokazuje, ali samo u slučaju ako se osoba na koju se ukazuje realno ne dodirne. Na polju muzike ritam je pokretna sugestija jednog sukcesivnog slijeda koji sâm može biti popunjen dodatnim sugestijama. Ritam je najčešće izražen kao akustični fenomen ali može biti izražen i kao optički fenomen.

Sinestetski karakteri ne moraju biti identični sa sinestezijama. ${ }^{24}$ To su karakteri koje možemo primijetiti na čulnim fenomenima, kada su u pitanju pojave poput boje, zvukova, šumova, hoda, veselja, sjete, svježine, umora i sl. Na njima možemo opaziti da je nešto oštro, meko, tvrdo, toplo, hladno, masivno, teško i tome slično. Sinestetski karakteri mogu se odvojiti od čulnih kvaliteta, na primjer kada vlada tišina ne čuje se ništa, a ona ipak može imati sinestetski karakter. Način na koji izgovaramo pojedine riječi, intonacija, emotivno oživljen sadržaj, korespondencija između značenja i načina izgovora riječi čini ono izgovoreno sinestetski uvjerljivim. Čitavo tjelesno biće može biti uneseno u izgovaranje riječi koje ne bi trebale samo označavati neki predmet, nego i dočarati emocije, stanja stvari ili značenje tih izraza. Nježne poruke kazuju se umilnim glasom, naredbe ili ljutnja kratkim i oštrim. Svaka riječ može, noseći određeno značenje, kroz način na koji se izgovara, približiti ono što opisuje. Bezličnom govoru nedostaje sinestetski karakter. Primjećujemo da ne samo dužina riječi nego i dužina vokala pojačava sinestetski doživljaj onog što izgovaramo. ${ }^{25}$ Dobar primjer za to riječ je $d u g$, koja je sama po sebi kratka, tj. sastavljena od malog broja slova, ali je jedini samoglasnik koji se javlja u ovoj riječi, vokal $u$, izgovoren dugouzlaznim naglaskom, tako da se efekt oslikavanja značenja postiže parcijalnim sinestetskim segmentom.

Schmitz razlikuje dvije vrste antagonističkog utjelovljenja: jednostrano i naizmjenično. Jednostrano antagonističko utjelovljenje na djelu je kada je jedan od partnera u tjelesnoj komunikaciji izrazito aktivan, a drugi pasivan. $\mathrm{U}$ takvom vidu komunikacije čini se da je pasivna strana u odnosu potpuno fiksirana na aktivnog sudionika. Naprosto dominantniji partner jednostranog utjelovljenja ispoljava svoju moć kao da raspolaže svim pravcima u zajedničkom poticaju. Primjer koji Schmitz često daje u svojim djelima, kada je riječ o jednostranom utjelovljenju, jest promatranje hodača po žici. U situaciji kada gledaoci promatraju akrobata, oni do te mjere bivaju fascinirani njegovim umijećem balansiranja da i sami prave nesvjesne tjelesne pokrete kao rezultat napetosti koja se stvara u njihovim tijelima. Svaki nagovještaj gubljenja ravnoteže akrobata na žici kod promatrača zaustavlja dah, povećava uzbuđenje, stvara spontane pokrete i nesvjesno grčenje mišića. Schmitz, također, daje primjer padajućeg predmeta koji do te mjere može zaokupiti pažnju subjekta 
da ovaj naprasno biva privučen pratiti, najprije pogledom, a onda i cijelim tijelom, poniruće nestajanje, što može imati i fatalne posljedice ako se osoba koja je fiksirana na aktivnog sudionika nalazi na visokoj zgradi, planini ili bilo kojem drugom uzvišenju. Izrazit primjer jednostranog utjelovljenja jest $i$ primjena hipnoze koju Schmitz nastoji objasniti putem svoje koncepcije tjelesne komunikacije, a ne čisto fiziološki ili psihološki. On naglašava da pogled čovjeka koji će biti hipnotiziran mora ići u prazninu kako bi hipnotizer mogao utjecati na tjelesnu dinamiku te osobe, a da pri tom sâm izbjegne pogled osobe koju hipnotizira kako ne bi podlegao efektima hipnoze.

Druga je vrsta antagonističkog utjelovljenja naizmjenično antagonističko utjelovljenje. U takvoj tjelesnoj komunikaciji neprekidno se premoć prebacuje s jedne na drugu stranu. Ona fluktuira shodno ritmičkom kretanju i dinamici dominantnosti, napetosti i nabreknuća u vitalnom poticaju pojedinaca. Partneri u takvoj vrsti tjelesne komunikacije u kratkim vremenskim intervalima razmjenjuju premoć kao kad se u teniskom meču razmjenjuje loptica. Paradigmatski, može se to prikazati na primjeru razgovora dva čovjeka u kojemu se raspon uključenosti sudionika može kretati od potpunog neslušanja i dekoncentriranog prisustva do apsolutnog unošenja i prožimanja u razmjeni verbalnih i neverbalnih poruka u cjelovitoj komunikaciji i fokusiranosti na odnos. Ono što sugovornici očekuju jedni od drugih nije samo razumijevanje i odobravanje izgovorenih riječi, nego i uvažavanje i priznavanje tjelesne prisutnosti partnera u razgovoru. Kod emocije požude, očekujemo da druga strana u odnosu na naše otkrivanje želje odgovori prihvaćajući i potičući uzajamnu erotsku razmjenu. Također, kada osjetimo strah od neke osobe ili životinje, ona dobiva poticaj i snagu da smjelije krene, što od nas dalje iziskuje adekvatnu reakciju obrane ili bijega, čime se utemeljuje dinamika slijeda uzajamnih akcija i reakcija. Opisujući momente bliske naizmjeničnom antagonističkom utjelovljenju, Schmitz opisuje situaciju u kojoj nam se može učiniti da u vidokrugu imamo čovjeka kojeg percipiramo, a da se kasnije ispostavi da je to neka lutka ili model koji imitira i simulira ljudske pokrete. $U$ trenutku kod čovjek otkrije da nije komunicirao sa živim bićem može se kod njega javiti zbunjenost, otpor i nelagoda.

Pored, ovih ukratko predstavljenih, vidova utjelovljenja, Schmitz je govorio i o solidarnom utjelovljenju kao posebnoj vrsti utjelovljenja. Solidarno utjelovljenje sušta je suprotnost antagonističkom i dešava se kada ljudi ili životinje bez direktnog obraćanja potpadaju pod zajednički vitalni poticaj. Dobri primjeri za to su masovna panika (koja nastaje uslijed neposredne opasnosti

22

Pokretne sugestije ili sugestije kretanja jesu anticipacije pokreta koje se mogu primijetiti na oblicima koji se kreću, ali i na onima koji miruju. Oni nadilaze mjeru i opseg izvedenog pokreta i do te mjere sugestivno djeluju na promatrača da on nesvjesno pokreće svoje tijelo u skladu s onim što vidi.

23

Sinestetski karakteri intermodalna su svojstva (prolaze kroz različite čulne regije) koja često nose naziv specijalnih čulnih kvaliteta, ali mogu se pojaviti i bez njih.

24

Sinestezija je stapanje ili ujedinjenje osjeta. Iako doživljavamo samo jedan osjet, javljaju se prirodne i spontane asocijacije i stapanja s raznorodnim drugim osjetima. Dolazi do fuzije kanala; npr. zvukovi rađaju određena vizualna iskustva poput boje ili oblika i u tom slučaju čujemo boje, vidimo zvuk, ili imamo utisak da nas neki blagi tonovi dodiruju. Također, određene vizualne senzacije i draži mogu izazvati zvučna ili mirisna iskustva. Usp. Damir Smiljanić, Sinestetika. Skica patičke teorije saznanja, Adresa, Novi Sad 2011., str. 70-94.

25

O sinestetičkim kvalitetama jezika i govora usp. ibid., str. 213-239. 
u zatvorenim prostorima, prilikom stampeda na stadionima i sl.) ili slijeđenje ponašanja drugih (npr. na pješačkom prijelazu kada makinalno sledimo kretnje onih koje opažamo preko puta nas). ${ }^{26}$ Slučaj solidarnog utjelovljenja s jasno raspodijeljenim ulogama Schmitz ilustrira na primjeru dvojice drvosječa koji, dok pile grane, drže dva kraja pile. Uvjet da bi obavili posao siječe drva je prešutna usklađenost njihovih pokreta. Međutim, solidarno utjelovljenje, npr. u slučaju usklađenosti radnji i melodija muzičara u orkestru, zahtijeva i dopunu kroz ono antagonističko u figuri dirigenta koji svima daje pravac zajedničkom poticaju jer kada ne bi bilo sažimanja kroz antagonističko utjelovljenje solidarno utjelovljenje samo bi se počelo realizirati, ali ne bi se u potpunosti ostvarilo.

Pored podjele antagonističkog utjelovljenja na jednostrano i naizmjenično, Schmitz pravi i razliku između latentnog i patentnog utjelovljenja. Patentno utjelovljenje doživljava se u parcijalnim osjetima i kretanjima određenih područja tijela koje on naziva tjelesni otok (Leibesinseln), npr. u glavi, u želucu, u grkljanu i drugim dijelovima. Nasuprot ovome, latentno utjelovljenje ima izvor u cjelovitim tjelesnim osjetima i kretnjama. ${ }^{27} \mathrm{Na}$ primjeru razgovora možemo sagledati prirodu obje vrste utjelovljenja. Kada je neko cijelim svojim bićem uključen u razgovor, njegovi tjelesni otoci miruju (latentno utjelovljenje), a ako se ona na neki način jave, kroz osjete u tim regijama, utjelovljenje postaje patentno. Lantentno utjelovljenje može svakog časa postati patentno kada partner napravi neki neočekivan pokret prema onome tko se uživio u odnos ili kada je tijek razgovora kod slušaoca izazvao ushićenje i oduševljenost pa on u tom momentu izlazi iz do tada cjelovite integriranosti i involviranosti u razgovor, postajući svjestan svog ushićenja i tjelesne regije gdje se ono javlja. Patentnim utjelovljenjem možemo nazvati i bilo koje naše stanje odsutnosti i dezintegriranosti kojem nedostaje osjećaj cjelovite povezanosti dijelova tijela. Poticaj za integraciju dezintegriranih otoka može biti bilo koji sadržaj ili osoba prema kojima otvaramo svoj komunikacijski kanal kakav u cjelini angažira našu pažnju i uključenost. Na tjelesnom planu osjećamo kako se pojedini dijelovi tijela utišavaju te cjelokupno biće postaje živo, povezano i usmjereno k jednom zajedničkom poticaju. Ponekad je teže detektirati stanje latentnog utjelovljenja od patentnog, može se reći da se ono i pojavljuje rjeđe. Češce se nalazimo u stanju parcijalnih osjećaja izazvanih nasrtajem na neke posebne tjelesne otoke, nego u stanju obuzetosti koje isključuje ili utišava sve ove nasrtaje na čovjekovu integriranost. Razlog tome leži u činjenici da se naša svijest može vrlo lako usmjeriti na pojedine tjelesne otoke koji trpe neku vrstu osjeta, ali teže je u sebi razviti cjeloviti doživljaj tijela nad kojim dominira neko stanje npr. radosti, ushićenosti ili koncentriranosti.

Najvažniji receptor ili medij uz pomoć kojega se patentno i latentno utjelovljenje zbiva držanje je (Fassung). Ono predstavlja određenu vrstu ospoljenja u okviru kojeg se realiziraju i patentno i latentno utjelovljenje. Schmitz će pomalo tautološki reći:

»Držanje je ono što izgubimo kad izgubimo držanje. Ono ujedinjuje tjelesnu dinamiku s razinama personalne emancipacije i neophodno je za stabilizaciju osobe. $\aleph^{28}$

Držanje nije bitno samo za osobnu afirmaciju i oslobađanje, nego i kao potvrda vlastitosti u komunikaciji s drugima. To se posebno vidi na primjeru pogleda kojim se može izvršiti premoć ili dominacija jedne osobe nad drugom, poslati značajna poruka ili izraziti stav. Nadmoći nečijeg pogleda čovjek može suprotstaviti cjelokupno svoje držanje s kojim se identificira u danom momentu. ${ }^{29}$ Schmitz čak govori o mogućoj konfrontaciji držanja i pogleda 
u sklopu antagonističkog utjelovljenja osoba. U određenom odnosu dva čovjeka, između kojih je došlo do sukoba, ili se odvija proces zavođenja, uvjeravanja ili bilo kojeg drugog vida manipulacije, jedan partner na posebno sugestivan način gleda drugog, a ovaj mu suprotstavlja cjelokupno držanje svog tijela koje istura u prvi plan. Međutim, s obzirom na to da se u samom pogledu manifestira određeni stav kao držanje, to znači da se u danom odnosu jedno držanje suprotstavlja drugom. Ta dva držanja u zajedničkom pokušaju utjelovljenja nastoje se uklopiti. ${ }^{30}$

U djelu Što je nova fenomenologija? Schmitz navodi zanimljiv primjer, ${ }^{31}$ opisujući situaciju u kojoj čovjek nježne konstitucije, esteta, dolazi u posjetu kod svog kolege, poete, koji je krupan i atletski građen. Atleta mu u jednom momentu razgovora priopći svoju skrivenu želju da bar jednom u životu iskusi pogled i držanje čovjeka kojeg bi on bacio kroz prozor, kako bi imao neposredan doživljaj gledanja ljudskog straha na licu osobe koja munjevitom brzinom anticipira neposrednu opasnost i vrlo izvjestan kraj koji može uslijedi. Dok atleta priopćuje svoju potajnu želju sugestivnim, ozbiljnim i odlučnim glasom, gledajući svog kolegu s nekom čudnom odrješitošću, ovaj u trenutku shvaća da se ono što njegov sugovornik govori, kao svoju želju i namjeru da doživi, može upravo na njega odnositi. Ta ga spoznaja prožima, mijenjajući cjelokupno njegovo držanje, i u tom momentu, zbog straha koji ga obuzima, on počinje panično reagirati.

\subsubsection{Istjelovljenje}

Pandan utjelovljenju u sklopu tjelesne komunikacije jest istjelovljenje (Ausleibung). Istjelovljenje je utapanje u komunikaciju s nepredmetnom širinom

26

Imitiranje pokreta drugih na nesvjesnoj fiziološkoj razini prisutno je kod zijevanja. Naime, ukoliko se nađemo u prisustvu nekog tko počinje zijevati, utoliko naše rudimentarno praćenje radnji drugih u ovakvoj situaciji dolazi do izražaja time što automatski i mi sami počinjemo nekontrolirano oponašati te pokrete.

27

Kad osjećamo umor, on može biti ograničen na pojedine dijelove tijela, npr. ruke, noge, leđa (patentno utjelovljenje) ili možemo osjećati da cjelokupno naše biće prožima to isto osjećanje malaksalosti i nedostatka snage (latentno utjelovljenje).

28

H. Schmitz, Der Leib, str. 45. O koncepciji personalnosti usp. str. 71-87.

29

Michel Foucault tvrdi da je držanje tijela važno za uspostavljanje identiteta $\mathrm{i}$ ispunjenje uloge koju netko ima u društvu. Već po držanju tijela izdaleka se prepoznaje da je netko npr. vojnik. Vrlo rano shvaćeno je da se tijelom može manipulirati, da se ono može pokoravati i dresirati i da je adekvatan instrument $\mathrm{u}$ demonstraciji sile i moći. Međutim, Foucault ističe kako je osamnaesto stoljeće donijelo nešto novo u načinima nadziranja kažnjavanja tijela. Naime, ne promatraju se tijela više zbirno, nego je pažnja usmjerena na pojedinca. Razvijene su metode torture ciljno specificirane na jednu osobu. Otkriven je opseg kontrole koji podrazumijeva stalnu disciplinu, ograničenje kretanja, precizan vremenski slijed aktivnosti koje tijelo izvodi, stalni nadzor, točno uvježbavanje: pokreta, ponašanja i radnji pojedinca. Usp. Mišel Fuko [Michel Foucault], Nadzirati i kažnjavati. Rođenje zatvora, prevela Ana A. Jovanović, Prosveta, Beograd 1997., str. 153-177. 30

Međutim, moramo imati na umu da svako uklapanje nije i usklađivanje. Uklapanje bismo najbolje mogli odrediti kao slijed poteza $i$ akcija u međusobnom dijalogu razmjene snaga. Segmenti u odnosu dovoljno su uklopljeni kada se tijek razmjene izazova i odgovora ne prekida pobjedom jedne od strana, nego se relacija suprotstavljenosti i borbe održava i produžava. Usklađivanje bi podrazumijevalo precizno i suptilno podešavanje ponašanja i pokreta dvije osobe u odnosu, koje bi za svoj rezultat i cilj trebalo imati stvaranje harmonije i ravnoteže snaga između njih.

31

Usp. H. Schmitz, Was ist Neue Phänomenologie?, str. 162-163. 
koja nas okružuje. Tipičan primjer koji Schmitz daje, da bi objasnio istjelovljenje, opis je situacije neposredne opasnosti u koju može zapasti vozač na autoputu. Naime, dok je njegova pažnja usmjerena na pokrete koji se mogu i mehanički izvoditi, on ne griješi u slijedu i kombiniranju svjesnih, automatskih i mehaničkih radnji. U situacijama kada se prelazi dobro poznat put ili kada se vožnja odvija monotonim tijekom, bez puno iznenađenja i potrebe za dodatnim manevriranjem, moguće je u svojoj fokusiranosti na neki tjelesni otok ili misao bez problema obavljati radnju vožnje. Međutim, momentu kada se pogled vozača krene stapati s okolinom, kada se širi i kada se pažnja s tjelesnih otoka ili konkretnih pokreta prebaci i utopi u nepreglednu širinu koja ga okružuje, tada postoji mogućnost da izgubi kontrolu nad vozilom i sebe dovede u opasnost. Schmitz daje i pozitivne primjere istjelovljenja kao što je predanost kroz mističko sjedinjenje s Bogom. ${ }^{32}$ Istjelovljenje predstavlja utapanje u ono što nam kroz svoju širinu daje osjećaj povezanosti i integriranosti kojom se nadilaze granice vlastitog tijela.

»Istjelovljenje je tjelesna komunikacija s neizmjernom (...) širinom putem izdvajanja privativnog širenja iz nabreknuća $u$ vitalnom poticaju, s tim što se napetost i od nje istaknuta uskoća tijela (...) rastvaraju u širinu. $\ll^{33}$

Istjelovljenje se može ilustrirati i na primjeru čovjekovog povezivanja i stapanja s prirodom. Doživljaj uzvišenosti, snage i postojanosti prirode proizvodi kod čovjeka želju da u potpunosti doživi ovu ljepotu kroz cjelovito prepuštanje i spajanje s njom. Ćovjek se povezuje i utapa u cjelinu osjećajući da su izbrisane granice njegovog tijela $\mathrm{i}$ da je na neki način stopljen s predjelom koji ga je očarao.

\section{Primjena koncepta tjelesne komunikacije na problem razumijevanja izraza}

Da bismo pokazali plodnost Schmitzove ideje o dinamici tjelesne komunikacije, prikazat ćemo način na koji se shvaća tjelesni izraz u sklopu njegovog učenja. ${ }^{34}$ Schmitz uvodi kategoriju izraza u sklopu svoje teorije priopćavanja (Mitteilung). Razlikuje tri tipa priopćavanja: obavještenje, simptom i izraz. U slučaju obavještenja radi se o jezičkoj ili znakovnoj radnji u kojoj se ono priopćeno sastoji iz pojedinačnih stanja stvari, programa ili problema $;{ }^{35} \mathrm{kod}$ simptoma to se priopćeno pojavljuje u konstelaciji stanja i događaja koji se mogu rekonstruirati kao kauzalni, dok kod izraza ono priopćeno leži u smisaonim implikacijama mnogokazujućeg utiska (der vielsagende Eindruck). Zanima nas posljednji slučaj, tj. način priopćavanja putem izraza i samim time bavit ćemo se kategorijom utiska.

Mnogokazujući utisak može imati veliki broj značenjskih slojeva. Utisak je određena vrsta situacije, ali on se mora razlučiti od drugih oblika i vrsta. Situaciju može činiti i osobnost jednog čovjeka i njegova osobna situacija u koju je uključen veliki broj drugih situacija (njegova stanovišta, interesi, ćud, njegova tehnika identifikacije sa socijalnim ulogama, slike koje odražavaju njegove stavove i ideale, fragmenti njegovih sjećanja i sl.). Sve te pojedinačne situacije mogu biti uključene u nadosobne ili čak neosobne situacije, a one mogu biti povezane sa stjecanjem govornih kompetencija kao što su jezici, govorne forme i sl.

»Priopćavanje putem izraza mnogokazivanje je mnogokazujućeg utiska tj. opaženo prisustvo njegovog kaotično mnoštvenog, cjelovitog značenjskog sloja s mnogo ili manje eksplikacije pojedinačnih stanja stvari, programa i problema iz njega.« ${ }^{36}$ 
Kolika je snaga mnogokazujućeg utiska možemo vidjeti na primjeru fasciniranosti nečijim izrazom lica ili emocijom koja je na njemu prisutna. Ne samo lice, nego i cjelokupna pojava nekih ljudi ponekad na nas može djelovati potresno i opčinjavajuće, a da pri tome nismo u mogućnosti dokučiti ili razlučiti što nas konkretno toliko fascinira. U takvim momentima obuzeti smo i okupirani onim što nas inspirira i uzbuđuje. Ono što ostavlja snažan utisak ne krije se u nekom pojedinačnom segmentu te situacije susreta s drugim, nego jaku impresiju ostavlja upravo ta cjelina prožimajuće kaotične mnoštvenosti. Kasnije se može dogoditi da mi nismo u stanju sjetiti se npr. cjeline lica koje nas je fasciniralo ili rekonstruirati njene pojedine osobite dijelove, ali do te mjere nadvladava utisak koji je osoba ostavila na nas da ćemo vrlo lako prepoznati to lice kada ga ponovo vidimo iako nismo u mogućnosti u ovom momentu u cjelini ga opisati ili zamisliti. Jaka impresija koju je ta ličnost ostavila na nas uvijek će izazivati prepoznavanje čak i ako je sjećanje na nju necjelovito i nejasno. ${ }^{37}$ Sljêdeći i dalje razvijajući Schmitzovu teoriju tjelesne komunikacije, pojmovima izraza i mnogokazujućeg utiska možemo priključiti i jednu novu sintagmu - tjelesno sjećanje ili sjećanje tijelom. Tijelo ne zaboravlja jake utiske, koji su se poput žiga utisnuli u perceptivnu memoriju kojom se možemo »vratiti u prošlost « i oživljavati neke davnašnje mirise, ukuse, oblike, glasove, predjele ili dominantnu atmosferu nekog mjesta, vremena ili situacije. Sjećanje tijelom iz mnoštva snažnih i značajnih utisnutih impresija približava svijesti svo to sjećanje, stapajući ga u jedinstveni osjećaj mira, spokojstva, bezbrižnosti, bezvremenosti i sigurnosti kojeg, u nostalgičnom vraćanju u prošlost, vezujemo za djetinjstvo ili neka ranija vremena. Više ne postoji taj nekadašnji svijet i čitav poredak stvari i odnosa koji je u njemu funkcionirao, ostalo je samo mnoštvo mnogokazujućih utisaka koje tijelo pamti kao sjećanje na to minulo vrijeme.

32

Moglo bi se ekstatičko stapanje s Bogom shvatiti kao jedna vrsta istjelovljenja. Izvorno riječ ekstaza znači »istupanje«, »stajanje izvan sebe«. U tom stanju čovjek u zanosu i blaženih čuvstva »izlazi« iz samog sebe i spaja se s višom cjelinom, s Bogom, Apsolutom. Doživljaj su ekstatičkog zanosa novoplatoničari opisivali kao najviše stanje radosti i ushićenja u kojem gubimo osjećaj vlastitog tijela i situacije u kojoj se nalazimo i neposredno »gledamo« Božju sućinu. U kršćanskom učenju ekstatičko bivanje izvan sebe predstavlja najviši vid kontemplacije.

33

H. Schmitz, Der Leib, str. 50 .

34

Koncepcija se tjelesnog izraza $u$ filozofiji počela intenzivnije razvijati u drugoj polovini devetnaestog i početkom dvadesetog stoljeća (Darwinova teorija mimike i gestikulacije, Diltheyeva hermeneutika izraza, Klagesova nauka o izrazu, Plessnerovi radovi o smijehu i plaču itd.)

35

Pobliže ćemo na primjerima pokazati kako Schmitz određuje ova tri pojma: stanje stva- ri, program i problem. Stanje je stvari npr. zbunjenost, razdraženost, nelagoda i sl., program predstavlja način na koji se ja ponašam $\mathrm{i}$ ophodim u danom stanju, a problem je to što mi nikada nismo u mogućnosti poznavati cijelu situaciju koja se vezuje za dano stanje. Sve to sažima se u jedan utisak. 36

Hermann Schmitz, Höhlengänge. Über die gegenwärtige Aufgabe der Philosophie, Akademie Verlag, Berlin 1997., str. 121.

37

Takva situacija javlja se npr. kada ponovo sretnemo osobu iz mladosti koja nam je bila emotivno vrlo bitna, a koju dugo nismo vidjeli i koja se u međuvremenu na fizičkom planu, $\mathrm{u}$ određenoj mjeri, promijenila. U momentu susreta još uvijek ne znamo tko je osoba koja je pred nama, zbog promjena koje je tijekom godina pretrpjela, ali možemo registrirati da je naše tijelo, poneseno davnašnjim utiskom i fascinacijom, ponovo reagiralo burno. Iako još nismo prepoznali koga smo to ugledali, osjećamo uznemirenje i uzbuđenje u tijelu. Tijelo pamti i reagira na isti način kao nekada. 
Schmitz je zaslužan za formuliranje određene teorije osjećanja koja njih ne smatra unutrašnjim stanjima čovjeka, nego atmosferama koje zahvaćaju subjekt. ${ }^{38}$ Stoga, utisak treba sagledati i u svjetlu atmosferičke teorije osjećanja (teorije osjećanja kao atmosfere) jer on postaje izražajan i upečatljiv kada je ispunjen atmosferama osjećanja. Kao što promjena sredine (npr. izlazak iz zadimljene prostorije na svjež zrak) obuzima čovjeka tako da on to osjeća u cjelini te mu donosi olakšanje i doživljaj potpuno nove situacije, tako i osjećanja u momentu mogu zahvatiti čovjekovo tijelo. Dakle, utisci posebno razvijaju svoj efekt time što su ispunjeni tj. nabijeni tim osjećanjima. ${ }^{39}$ Uzmimo kao primjer slučaj kada vozač automobila u tijeku vožnje, uslijed loših vremenskih uvjeta na cesti, za trenutak izgubi kontrolu nad vozilom, pa mora munjevitom brzinom reagirati kako bi izbjegao opasnu situaciju. Utisak neposredne opasnosti, koji on ima, ispunjen je cjelovitom perceptivnom procjenom instinktivnog, kao i brzomislećeg, reagiranja u kojem su u jedno stopljeni informacija o relevantnim segmentima situacije, procjena opasnosti, odluka o načinu djelovanja i cjelokupna angažiranost tijela koje reagira na danu situaciju. Reakcija vozača, koji ponovno nastoji uspostaviti kontrolu nad vozilom, proizvod je sažimanja mnogobrojnih segmenata situacije koji se stapaju u jedan cjelovit utisak.

Da bi ukazao na značaj razumijevanja i tematiziranja pojma izraza u sklopu svoje teorije tjelesne komunikacije, Schmitz koristi jedan primjer koji se može naći kod filozofskog teoretičara izraza Ludwiga Klagesa. ${ }^{40}$ Klages opisuje trenutak u kojem žena, ugledavši svog muža koji je došao kući, odmah na njegovom licu i u cjelokupnom držanju zapaža neku vrstu razdraženosti, a kod sina tiho neraspoloženje. Međutim, kada bi trebalo objasniti na osnovu kojih karakteristika lica i dijelova tijela tako jasno uočava navedena stanja ona nije u mogućnosti razlučiti, precizirati i objasniti. Ono čega ona neposredno biva svjesna jest prepoznato stanje na osnovu utiska sklopljenog od mnoštva informacija o cjelokupnom držanju tijela i izrazu lica.

Utisak nije neki isključivo subjektivan, ili čak proizvoljan, doživljaj drugog ili bilo koje situacije i događaja koje intenzivno proživljavamo. Nemogućnost da jasno navedemo elemente koji čine utisak, kao i odnose između ovih elemenata, nije pokazatelj njegove iracionalnosti ili nejasnosti, nego dokaz složenosti koja ne može u cjelini biti prepričana i rekonstruirana. Iako čovjek ne posjeduje poseban spoznajni organ kojim bi precizno razumijevao i definirao način izražavanja različitih stanja, npr. zbunjenosti, utučenosti, razdraženosti, mrzovolje i sl., svejedno ih može razlikovati. Razlog leži u tomu što mi nikada ne opažamo samo posebna obilježja, niti u opažanju konstruiramo predmete kao slučajeve klasifikacije na osnovu obilježja, nego direktno opažamo situacije i utiske koji su po sebi evidentni i kojima nije potrebna simbolizacija ili reprezentacija kroz druge znake jer oni već automatski u sebi sadrže stanja stvari i programe i probleme, koji se onda mogu jezičkim sredstvima dalje eksplicirati. Iako Schmitzovo stanovište može na prvi pogled izgledati kao određena vrsta holističkog pristupa, upravo je osobitost njegova učenja u tomu što utisak ne promatra kao objedinjujuću harmoničnu cjelinu, nego kao kaotičnu mnoštvenost. Naglasak nije na jedinstvu cjeline, nego na združenosti i objedinjenom sveprožimajućem djelovanju skupine elemenata koji proizvode snažan utisak.

Razumijevanje izraza ne može se normirati ili podvesti pod pravila zbog njegove neprenosivosti i neprevodivosti i prema tomu se on sućinski razlikuje od obavještenja i simptoma. Izraz ne može biti reguliran putem nekih fiksnih pravila prevođenja, kao što je to moguće na razini obavještenja, npr. neko 
obavještenje može se prenijeti iz jednog modusa u drugi putem različitih medija. Također, simptom je moguće prenijeti u obavještenje kada se npr. izmjeri temperatura tijela, gdje se na osnovu dosegnute oznake za temperaturu u toplomjeru određuje stanje tijela. Međutim, za razliku od obavještenja i simptoma, izraz nije moguće prevesti pomoću drugih sredstava ili medija. Kako prenijeti oholost, veselost, tugu ili entuzijazam tjelesnog izraza? Prema Schmitzu, to je neizvedivo. Iz te neprenosivosti izraza slijedi nemogućnost njegovog reguliranja. Zato se Schmitz opire nastojanju da se tjelesni izraz asimilira u semiotici kao općoj nauci o znakovima.

Jedno od ključnih pitanja koje, u okviru ove problematike, razmatra Schmitz sljedeće je: na koji je način čovjek prijemčiv za primanje utisaka? On smatra da se mogućnost doživljavanja i primanja utisaka odvija kroz utjelovljenje. Da bi prikazao na što vjerodostojniji način ovaj proces, on u diskusiju uvodi pojam uosjećavanja (Einfühlung). ${ }^{41}$ Čovjek može razumjeti stanja drugog kada se unese u ono što taj drugi proživljava i osjeća. Prema Schmitzu, mogu se razlikovati tri vrste uosjećavanja: projekcija, podražavanje i fascinacija. ${ }^{42}$ Projekcija se zbiva kada se bilo koji subjektivni podaci učitavaju u ponašanje i osobnost drugog. Podražavanje je preuzimanje nekih izražajnih kretnji i motoričkih gesti koje se mogu naučiti bilo striktnim podučavanjem bilo promatranjem i imitiranjem same radnje i onoga tko izvodi pokrete. Međutim, Schmitz tvrdi da se razumijevanje izraza ne može dobiti niti putem projekcije niti putem podražavanja, nego samo putem fascinacije. Fascinacija je, u punom smislu te riječi, uosjećavanje, ali i više od toga, podrazumijeva gubljenje razlike između subjektivnog i objektivnog. Da bi predstavio i objasnio kako bi trebalo razumjeti fascinaciju, Schmitz nam predočava primjer promatranja akrobata u cirkusu koji je preuzeo od psihologa Theodora Lippsa, o čemu je prethodno bilo riječi. ${ }^{43}$ Pojedini dijelovi tijela posebno doživljavaju i osjećaju kretnje drugog, tako da se stanje uosjećavanja pojavljuje kao utjelovljenje iz-

38

Koncizan prikaz njegove teorije osjećanja vidi u: Hermann Schmitz, »Gefühle als Atmosphären und das affektive Betroffensein von ihnen«, u: Hinrich Fink-Eitel, Georg Lohmann (ur.), Zur Philosophie der Gefühle, Suhrkamp Verlag, Frankfurt am Main 1993., str. 33-56. Također u kratkim crtama usp. D. Smiljanić, Sinestetika, str. 191-203.

39

Mada Schmitz smatra da mogu postojati i utisci koji dotičnu osobu pogađaju tjelesno, a da nisu u tom slučaju ispunjeni atmosferama osjećanja.

40

Usp. Ludwig Klages, Grundlegung der Wissenschaft vom Ausdruck, Bouvier, Bonn ${ }^{7} 1950$., str 52

41

U tom kontekstu značajna je teorija simpatije koju je razvio fenomenolog Max Scheler. Schmitz uviđa vrijednost ove teorije, ali ističe i njene nedostatke. Scheler smatra da stav koji zauzima filozof, a koji bi, prije svega, trebao biti moralan, jest ključan za otkrivanje i sagledavanje fenomenološki relevantnih činjenica. Sućina filozofskog razmišljanja i istraživanja morala bi se temeljiti na ljubavi kao poticajnoj snazi. Scheler je razvio učenje o stupnjevima razvoja oblika simpatije. On ljubav i simpatiju uzima kao iskustveno nesvodive prafenomene psihičkog i duhovnog bitka. »Etika simpatije polazi od toga da moralna vrijednost ne zavisi primarno od bitka i načina ponašanja osoba, njihova osobnog bitka i takobitka, djelovanja i htijenja itd., nego je tek hoće izvesti iz ponašanja promatrača (ili onoga koji osjećajno reagira na doživljaj i ponašanje drugoga), uvijek u osnovi pretpostavljajući ono što hoće izvesti.« Vidi: Maks Šler [Max Scheler], Bit i oblici simpatije, preveo Radivoje Kerović, Vidici, Banja Luka 2013., str 17.

42

Fascinacija se ne smije jednostrano razumjeti u smislu oduševljenosti nekime ili nečime, nego je fascinacija mnogo širi pojam i predstavlja apsolutnu vezanost $\mathrm{i}$ fokusiranost naše pažnje na promatran objekt.

43

Usp. Theodor Lipps, Ästhetik. Psychologie des Schönen und der Kunst. Erster Teil: Grundlegung der Ästhetik, Verlag von Leopold Voss, Hamburg, Leipzig 1903., str 122. 
među aktivnog akrobata i pasivnog promatrača koji se uživljava u svaki izvedeni pokret. U ovakvoj situaciji utjelovljenje nije izazvano usklađivanjem dvije osobe, nego fascinacijom koju jedna osoba i njene radnje izazivaju kod druge.

Schmitz navodi i primjer majke koja prestrašeno prati kretanje svog djeteta, dok se ono bezbrižno igra, jer je svjesna opasnosti koja prijeti od automobila koji nailazi. U tomu smislu, fascinacija ne mora biti samo nešto pozitivno, ako je, kao u ovom slučaju, povezana sa strahom od mogućeg tragičnog razvoja događaja. Također, fascinacija se može vezati za objekt koji nije živ, a koji je u pokretu, npr. kretanje lopte u nogometu ili nekoj drugoj igri. Kroz ovaj primjer, Schmitz pokazuje zašto bi trebalo odbaciti shvaćanje da fenomen uosjećavanja podrazumijeva simpatiju ili empatiju prema objektu. Obično se pretpostavlja da se osoba koja se uosjećava u stvari identificira s drugim, ali nije nužno da se promatrač poistovjećuje s predmetom na koji je fokusiran.

Iako se, prema Schmitzovu mišljenju, svako razumijevanje izraza može tumačiti kao vid tjelesne komunikacije, to ne znači i suprotno, da je svaka tjelesna komunikacija razumijevanje izraza. Potrebno je pronaći specifičnu razliku kako bismo mogli ukazati na tip komunikacije koji je važan za razumijevanje izraza. Schmitz to čini uvođenjem pojma naizmjeničnog utjelovljenja jer prethodni primjeri s akrobatom i loptom pokazuju nam jednostrano utjelovljenje. To znači da se ni akrobat ni lopta ne usmjeravaju gledaocu. Pojam naizmjeničnog utjelovljenja pomaže nam bolje razumjeti izraz drugog jer se kroz neprekidnu razmjenu i odnošenje odvija međusobno usklađivanje dvaju tijela. ${ }^{44} \mathrm{Na}$ taj se način sâmo razumijevanje doživljajnog izraza (Erlebnisausdruck) pokazuje kao primjer uzajamnog, patentnog ili latentnog, utjelovljenja.

\section{Zaključna razmatranja}

Schmitz je kroz svoju analizu perceptivnih oblika spoznaje i tjelesnih vidova komunikacije konceptualizirao doživljajne crte subjektivnosti, čime im je dao status i dignitet cjelovitog kognitivnog autoriteta, obuhvaćajući sve vidove čovjekove spoznajne aktivnosti. Pasivnu poziciju onog tko je afektiran postavio je u središte, imenujući afektivnu pogođenost onim stanjem koje čovjeka, kroz njegovu tjelesnost, čini aktivnim, otvorenim i spremnim za primanje utisaka.

Međutim, tradicionalni aspekti tjelesnosti potisnuti su suvremenim odnosom prema tijelu koji donosi napredne mogućnosti: korekcije čovjekova izgleda, postavljanje umjetnih implantata, transplantacija dijelova tijela, ugradnja umjetnih organa, modifikacija genetskog materijala itd. Uz pomoć novih tehnologija i znanja, čovjekovo tijelo u materijalnom se smislu unapređuje, podmlađuje i produžava mu se rok trajanja. Ėpšteîn ističe da se na prijelazu iz devetnaestog u dvadeseto stoljeće promijenila fizička slika svijeta, na mjestu "nestale« materije otkrivena je energija, a zatim je dalji pomak znanstvene misli išao od kategorije energije do kategorije informacije. Danas se čak i živa materija sve više razmatra kao način za čuvanje i prenošenje informacija i u tu svrhu čovjekovo tijelo trebalo bi odigrati ulogu informacijske matrice. U perspektivi ujedinjavanja organizma i računala, informatizacija tijela javlja se kao budući zadatak. ${ }^{45}$ 
Može se reći da je suvremeni čovjek postao manje tjelesan s obzirom na to da površnije i nedovoljno snažno osjeća. Tjelesnost se sve više genetski razumijeva i dešifrira, a sve manje čulno sagledava i doživljava. Na djelu su novi vidovi shvaćanja i upotrebe tijela - kao informacijske i memorijske matrice. Informacije o drugom tijelu prenose se elektroničkim putem uz pomoć novih tehnologija. U tomu smislu, zanimljivo je da je Schmitz, imajući u vidu nove vidove transformacije ljudskog tijela uz pomoć tehnike i tehnologije, njima suprotstavio izvorni pogled na potencijale čovjekove tjelesnosti:

»Otkriće, odnosno ponovno otkriće tijela [koje osjeća], tjelesne komunikacije, osjećanja kao atmosfera, mnogokazujućih utisaka, intradifuzne značajnosti situacija, moglo bi pokazati put u (...) otvorenost. Živjeti više iz [bića samog] tijela, osjetiti na goloj koži sunce, vjetar, pijesak i vodu i predavati se elementima, (...) moglo bi pored drugih, manje ekspanzivnih vježbi pomoći pri tomu da se manevarski prostor između primitivne i razvijene sadašnjosti još intenzivnije izmjeri, nego putem tehničkog napretka.« ${ }^{46}$

Schmitzov koncept tjelesnosti čuva sjećanje na osobitost, vrijednost i složenost tijela. Razrađeno učenje o komunikacionim aspektima tjelesnosti koji služe sporazumijevanju i međusobnoj razmjeni utisaka u cilju usklađivanja strana u odnosu mogu, kao duboki i istančani uvidi, biti inspirativni i korisni i suvremenima teorijama i znanostima. U ovim tehnološki i kulturološki izmijenjenim životnim uvjetima, Schmitzove ideje moraju biti primijenjene i na izmijenjen koncept života tijela i nove vidove konstrukcije i informatizacije tjelesnosti. Zanemarivanjem izvornih aspekata tijela koje osjeća ovaj svijet postaje »postljudski«, a tjelesnost se iz autentičnog modusa postojanja transformira u proizvoljan i promjenljiv materijal, čime se zbiva »odumiranje« tijela.

Ovaj fenomen Schmitz želi predočiti na posebnom primjeru kojeg naziva Eugenijin efekt, na osnovu Goetheove drame Prirodna kćer (Natürliche Tochter) u kojoj jedan vojvoda daje savjet svojoj kćerki Eugeniji da bude oprezna prilikom jahanja. Naime, ona s prevelikom smjelošću ulazi u odnos stapanja, utjelovljenja s konjem, tako da zbog energičnog i smjelog galopa otac strepi da se ne dogodi neka nesreća. Ona je kao strasna jahačica potpuno predana i stopljena s konjem koji poput rezonantnog tla prima impulse, koje ne prihvaća pasivno, nego ih aktivno vraća i pojačava. »U uzajamnom izrazu inicijative $i$ rezonancije jahačica $i$ konj razmjenjuju jedno s drugim zajednički impuls kretanja.« Vidi: Hermann Schmitz, Leib und
Gefühl. Materialien zu einer philosophischen Therapeutik, Junfermann-Verlag, Paderborn ${ }^{2}$ 1992., str. 195.

45

Tako Ėpšteîn ističe: »Suvremeno tijelo ili je predmet informacijsko-biotehničkog dešifriranja i transformacije ili je predmet trgovine i oruđe za profesionalnu karijeru (sport, top-modelski i pornografski biznis) ili samo ulog u političkoj borbi (i u tom smislu samo znak).« Vidi: M. Epštejn [M. Epstein], Filozofija tela, str. 19.

46

H. Schmitz, Ausgrabungen zum wirklichen Leben, str. 369. 


\section{Biljana Radovanović}

\section{Das Konzept der leiblichen Kommunikation bei Hermann Schmitz}

\section{Zusammenfassung}

Das Anliegen der Autorin ist die Darstellung des Begriffs der leiblichen Kommunikation bei Hermann Schmitz. Zunächst wird der Kontext umrissen, in dem dieser Begriff eingeführt wird - d. i. Schmitz' Philosophie, in der er auf die Erlebnisdimension der Leiblichkeit hinweist. Es werden die Hauptformen der leiblichen Kommunikation analysiert (Einleibung und Ausleibung) und durch Beispiele erläutert. Ein besonderes Augenmerk gilt dem Phänomen des Blicks. Das Konzept der leiblichen Kommunikation wird in einem eigenen Abschnitt auf das Problem des Ausdrucksverstehens angewendet. Am Ende wird die Autorin einen Blick auf die modernen Tendenzen des Umgangs mit der Leiblichkeit in der Informationsgesellschaft werfen.

\section{Schlüsselwörter}

Hermann Schmitz, Neue Phänomenologie, leibliche Kommunikation, Einleibung, Blick, Ausleibung, Ausdruck 